\title{
NEW CHALLENGES IN RURAL WATER MANAGEMENT IN POLAND - SELECTED PROBLEMS
}

\begin{abstract}
Józef MOSIEJ, Division of Ecological Engineering and Environmental Restoration, Faculty of Civil and Environmental Engineering, Warsaw University of Life Sciences-SGGW, Nowoursynowska str. 159, PL 02-776 Warszawa, Poland, jozef mosiej@sggw.pl Agnieszka BUS, Division of Ecological Engineering and Environmental Restoration, Faculty of Civil and Environmental Engineering, Warsaw University of Life Sciences-SGGW, Nowoursynowska str. 159, PL 02-776 Warszawa, Poland
\end{abstract}

State of rural water resources and selected new challenges of water resources management in rural areas in Poland are presented Problems of influence small water reservoir for water quality is presented. It is commonly believed that every kind of reservoirs should collect and reduce the nutrient contamination (N, P, heavy metals). The presented results show that water reservoirs (both pre- and main reservoirs) are a source of water pollution. The reservoirs fed by waters of inadequate or poor quality are an additional source of contamination, which accelerates the process of eutrophication. However, as the literature shows, well-designed pre-reserviors of optimum size can remarkably reduce the phosphorus import into reservoirs and help to control eutrophication from non-point sources

Keywords: BOD, good ecological status, phosphorous, small water reservoir, water quality.

\section{INTRODUCTION}

\section{Selected new challenges of management water resources in rural areas in Poland}

Water is a major environmental factor limiting agricultural production, since agriculture not only in Poland, is the largest user. Therefore, the problem of water balance in rural areas should be considered together with the issue of climate change observed in recent years. At the same time agriculture has a significant impact on the availability and quality of water.

Polish water balance analysis shows that the annual average production of biomass from agriculture consumes 65 billion $\mathrm{m}^{3}$ of water of about 180-185 billion $\mathrm{m}^{3}$ annually which comes from precipitation, which means high absorption of water in food production. Intensification of agriculture, including increased irrigated area (vegetables, orchards, meadows in river valleys) and increase the production of biomass for energy purposes and projected deficits associated with drought can be evaluated increase in the amount of water needed for agriculture to 10-20\% in 2030. As a result of climate change must also take into account the increase in the amount of water consumed by forests (gradual increase in forest area) and protected areas, which also affects the water balance of agricultural areas (Mosiej, 2011). The new challenge for widely understood water management in areas used for agriculture is precision farming, which for 10-20 years will be the dominant technology in crop production in large specialized farms. Before the science and practice are facing new challenges so that may relate to the following issues:

- increasing the role of agricultural advisory centers and institutes and research For which should increasingly provide information on agro-meteorological forecasts based on current meteorological forecasts derived from satellite observations, the state of vegetation in rural areas based on information from satellite and aerial imagery

- to develop models to optimize the use of scarce water resources, and therefore forecasting yields depending on the supplied amount of water for different rotations, different soil conditions and thermal conditions.

There will be probably an urgent need for new advisory services for highly specialized commodity firms/farms. Before universities is therefore the task of preparing specialists in the field of biotech systems engineering, biosystems engineering for specialist companies providing services in the form of the provision of current information, the need for irrigation and other agricultural treatments (fertilization, fertigation) due to the changing situation hydrothermal crops.

Projected climate change influence for create adaptation activity in economy. In agriculture sector in Poland was establish program "Effective adaptation to climate change in rural areas". In course of action "to create local monitoring and warning systems against threats," stressed the importance of universal access to measurement data and raw data bases for research institutions. In addition, as determined necessary educational activities and dissemination principles of good practice in the rural economy, and pointed out the need for implementing adaptation policy in the modernization of the Polish countryside and take full advantage of current opportunities for rural development. In course of action 
"organizational and technical adaptation of agricultural and fisheries to climate change" was recommended broadening the scope of activities to support the adaptation of agriculture to climate change on water conservation topics, including by avoiding the cultivation of requiring large amounts of water and through the use of hydrogels to improve retention in the soil. It also recommended stepping up research into the species resistant to prolonged droughts and frosts. Polish costs of adapting to projected climate change is estimated at 82 billion PLZ (app. 21 billion Euro) of which $43.5 \%$ agriculture, water management $15.3 \%$, forestry $4.6 \%$, spatial planning - $12 \%$. The cost of disposal losses for the years 2001-2011 amounted to a total level of 90 billion PLZ including agriculture almost 20 billion PLZ. In 2006 agricultural losses reached 15.5 billion PLZ, and spending on adaptation 8.7 billion PLZ. In the current funding period during 2014-2020 EU expenditure on adaptation to climate change will reach $20 \%$ of the total budget (MŚ, 2013).

The likely consequence of inaction adaptation will be a loss of about 86 billion PZE in 2020, which in the years 2021-2030 may reach up to 120 billion PLZ. The costs of inaction are based on an estimate of potential losses associated with climatic events, assuming that you have not taken any additional prevention and adaptation. Loss as a percentage of GDP generated during the period to grow slightly as compared to the loss in absolute terms. This is due to the fact that a large part of the increase will be richer losses caused to the society, the accumulation of wealth and capital, and the creation of new infrastructure.

Recent years have brought severe water deficit occurring in rural areas. Particularly noticeable negative effect is observed in areas of intensive crop production, where there is a shortage of water for irrigation. In order to improve the situation in terms of improving the water balance in Poland for 15 years carried out a multiannual program for the development of small water retention. This program applies to all activities aimed at extending the ways and increase the circulation time of water in catchment areas. Typically these are actions to stop the water in the basin through water in streams and retain water reservoirs. For the small retention include the construction of water reservoirs with a capacity of less than 5 million $\mathrm{m}^{3}$ (Mosiej, 2014)

A very important issue related to the implementation of the program for the construction of small water reservoirs is to shape the quality of water in these reservoirs, especially in the first years of their operation. Many studies have shown a deterioration of water quality in the reservoirs, when used for storing water from small rivers and channels with low flows (Jurik et al., 2015).

\section{The study of shaping the quality of water in small reservoirs in the first years of their operation - a case study}

Due to the ongoing discussions on the potential impact (positive or negative) of small water reservoirs on the environment and most of all the quality of water outflow from these reservoirs we started our research in the early periods of operation 2 small water reservoirs. Similar studies have been conducted in Poland in many other places in the first years of their operation (Bus and Mosiej 2013; Wiatkowski et al., 2013).

\section{MATERIAL AND METHODS}

The Cetynia River is small, lowland river located in west part of Mazowieckie voivodeship, Poland. It is a left

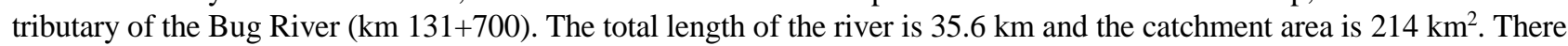
is located a complex of Niewiadoma Reservoirs: Kupientyn pre-reservoir (opened in 2004) of water surface of 2.25 ha and capacity of $28900 \mathrm{~m}^{3}$ and Niewiadoma main reservoir (opened in August 2013) of water surface of 42.22 ha and capacity of $1140000 \mathrm{~m}^{3}$ (Figure 1). The surface water samples from inlet and outlet of Kupientyn pre-reservoir and Niewiadoma Reservoir were collected 20-times during the period from October 2013 to September 2015. The first samples were taken three months after opening the main reservoir. There were identify: $\mathrm{P}_{-} \mathrm{PO}_{4}, \mathrm{BOD}_{5}$, turbidity, suspended soils, $\mathrm{pH}$ and electrical conductivity. The P-PO 4 was determinated by FIA Star (Foss) analyzer and BOD 5 by Oxi Top measure system.

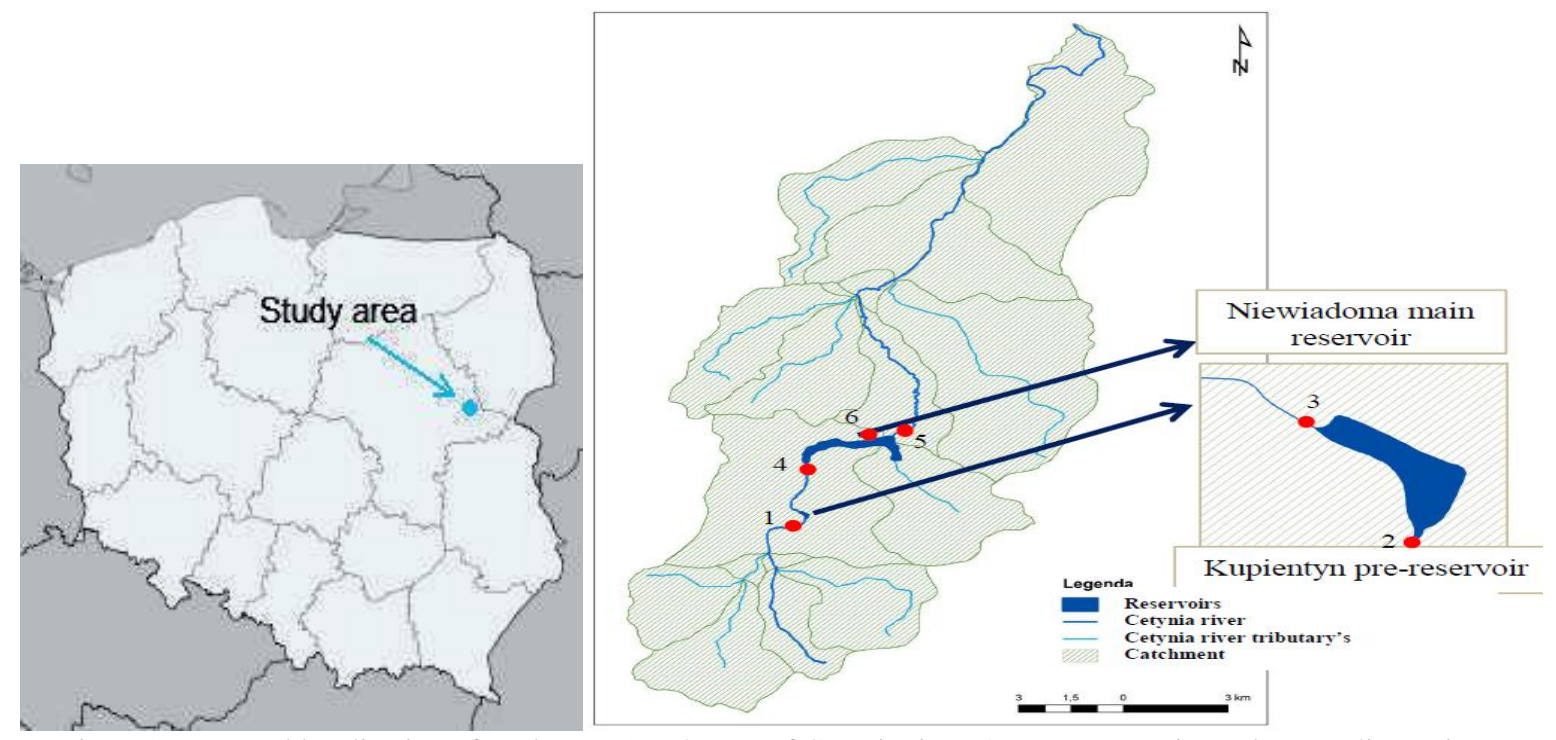

Figure 1. Map and localization of study area (catchment of Cetynia river, 2 water reservoirs and 6 sampling points). 
No. 1 sampling point is located above both the reservoir, at the Cetynia River, no. $2 \& 4$ sampling points are the inlets of Kupientyn pre-reservoir and Niewiadoma reservoir, respectively. No. $3 \& 5$ sampling points are the outlets of Kupientyn pre-reservoir and Niewiadoma reservoir, respectively. No. 6 sampling point is located on the right bank of Niewiadoma reservoir.

\section{RESULTS AND DISCUSSION}

The purpose of pre-reservoirs located immediately upstream of reservoirs is to improve the quality of the inflowing water by reduction of the loads of suspended matter and dissolved nutrients, phosphorus (Lothar, 2003). Because the phosphorus is a limiting factor of eutrophication process it is essential to reduce its contamination in surface water and sewage. Evan an addition of $1 \mathrm{~g}$ of $\mathrm{P}$ promotes the growth of up to $100 \mathrm{~g}$ of algae that represents the principal trigger of the eutrophication and toxic blue-algae blooms in the surface water (Drizo 2012).

The variability of $\mathrm{P}$, and $\mathrm{BOD}_{5}$ concentration, suspended soils, turbidity, $\mathrm{pH}$ and electrical conductivity indicating median, extreme values, average and quantile $25 \%$ and $75 \%$ is shown at Figure 2.
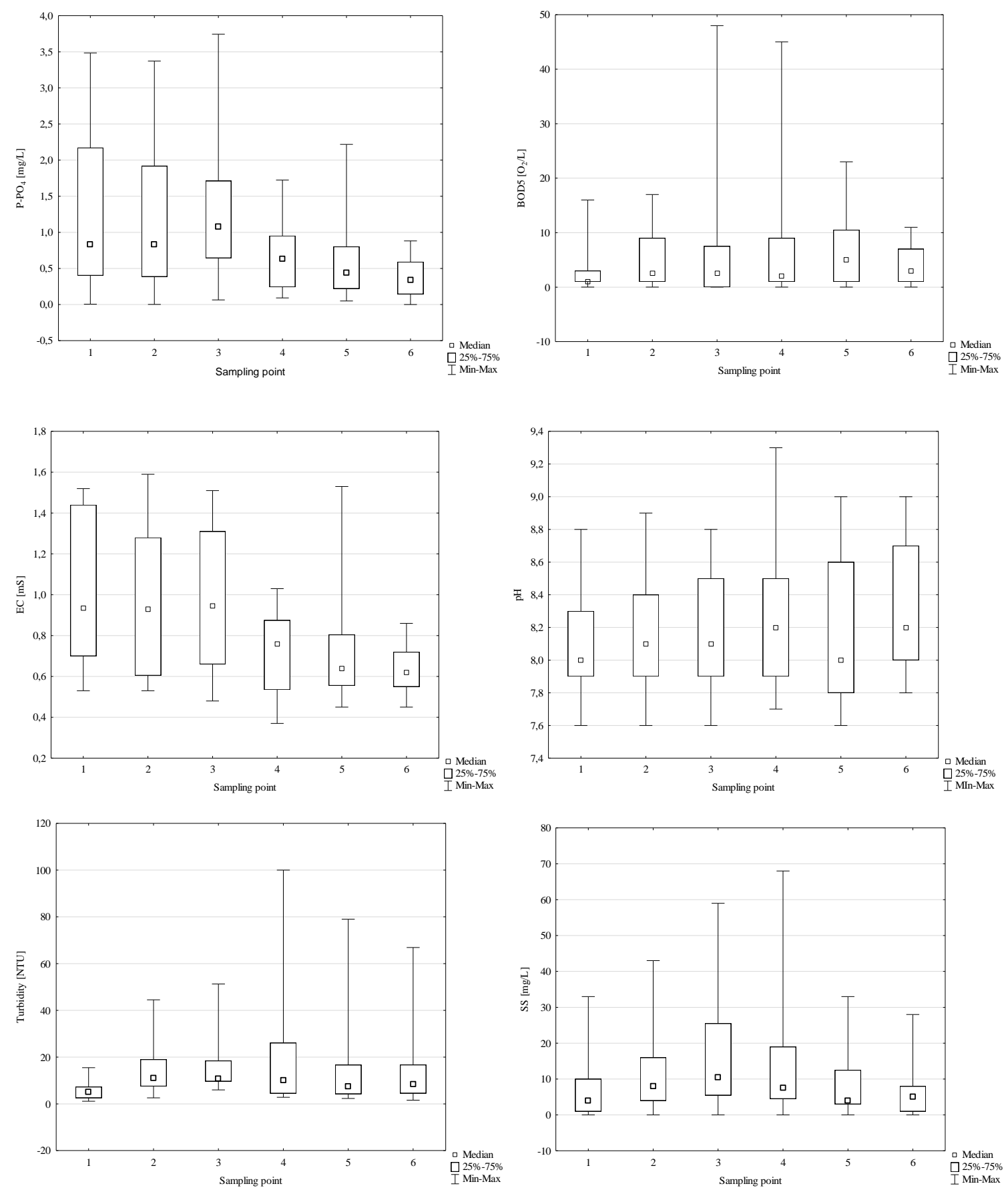

Figure 2. The variability of $\mathrm{P}_{-} \mathrm{PO}_{4}, \mathrm{BOD} 5, \mathrm{pH}$, electrical conductivity (EC), turbidity and suspended soils (SS) concentration at Cetynia River sampling points $(n=20)$. 
In case of Niewiadoma complex of Reservoirs, Kupientyn pre-reservoir does fulfill its main function. There is seen the influence of Kupientyn pre-reservoir on a phosphorous concentration of water of Cetynia river (Figure 2). The maximum and minimum $P$ values are almost two times higher above the exanimated pre-reservoir.
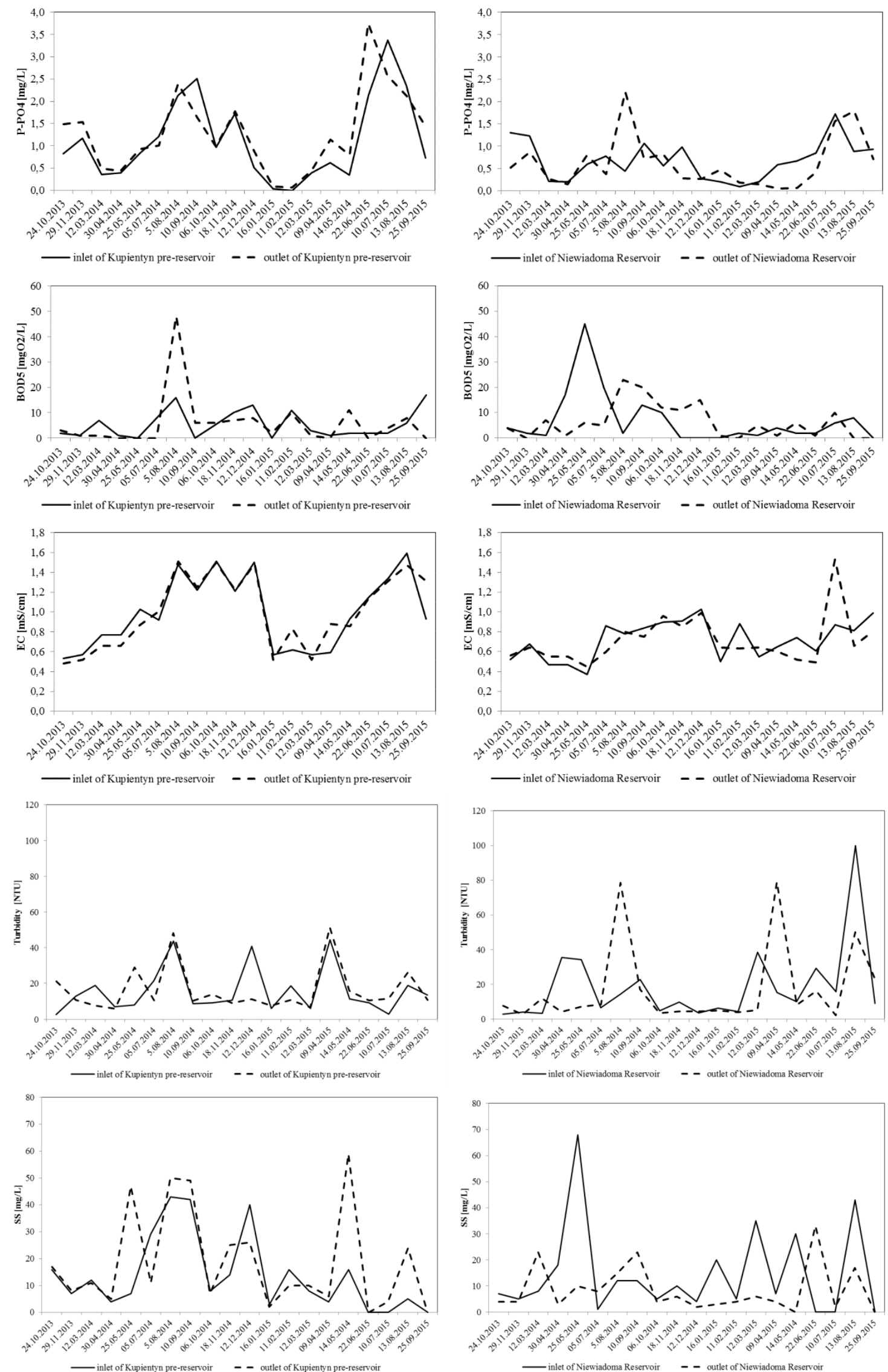

Figure 3. Monthly changes of P-PO4 and BOD 5 concentration, electrical conductivity (EC), turbidity and suspended soils (SS) at inlets and outlets of Kupientyn pre-reservoir and Niewiadoma main reservoir 
In case of BOD5 there is observed an increasing of concentration in case of Kupientyn pre-reservoir and decreasing concentration through Niewiadoma reservoir.

The median values of electrical conductivity are decreasing with water river flow. The $\mathrm{pH}$ values are on the same level at every sampling points. The variabilities of suspended soils and turbidity concentrations are the same for both indicators. There is observed an increasing of concentration through flow by Kupientyn pre-reservoir and decreasing in case of Niewiadoma main reservoir.

The inlets and outlets concentrations of $\mathrm{P}_{-} \mathrm{PO}_{4}$ during examined time of Kupientyn and Niewiadoma reservoir are presented in figure 3. However, during most of examined time, the concentration of $\mathrm{P}_{-} \mathrm{PO}_{4}$ were very high and more than limit value of good ecological status $(0.31 \mathrm{mg} / \mathrm{L})$. The highest concentration equals $2.504 \mathrm{mg} / \mathrm{L}$ at inlet of pre-reservoir (September 2014). However, the minimum value $(0.002 \mathrm{mg} / \mathrm{L})$ was also observed at inlet of pre-reservoir (February 2015). The concentrations of $\mathrm{BOD}_{5}$ that is the indicator of organic matter contamination at water, during examined time are also very high. Often the $\mathrm{BOD}_{5}$ value exceed the good ecological statue limit value $\left(6.0 \mathrm{mgO}_{2} / \mathrm{L}\right)$. The highest observed value was also for Kupientyn pre-reservoir and equals $48 \mathrm{mgO}_{2} / \mathrm{L}$ (August 2014). The high concentration of $\mathrm{BOD}_{5}$ may be caused by the intensive grow and withering away of duckweed during summer.

In case of the highest concentration of $\mathrm{P}_{-} \mathrm{PO}_{4}$ and $\mathrm{BOD}_{5}$ at Niewiadoma reservoir, that were observed during summer 2014 which was also linked with the intense growth of duckweed (Lemna minor L.). The electrical conductivity is an indicator that indicates of the degree of water salinity. The observed values in case of Niewiadoma reservoir are lower than at Kupientyn ones. The maximum value was observed at inlet to Kupientyn reservoir and equaled 1.59 mS/cm (May 2014). Turbidity is the cloudiness or haziness of a fluid caused by large numbers of individual particles. Turbidity can be caused by precipitating compounds of iron, manganese, aluminum salts; humid acid; plankton; particles of rocks and soils sediments.

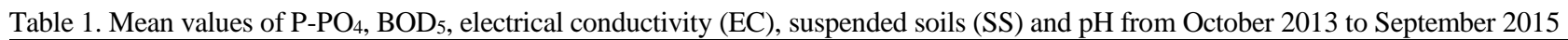

\begin{tabular}{|c|c|c|c|c|}
\hline Indicator & Sampling point & $\begin{array}{l}\text { Kupientyn } \\
\text { pre-reservoir }\end{array}$ & Niewiadoma reservoir & $\begin{array}{l}\text { The limits by Polish } \\
\text { law }^{1}\end{array}$ \\
\hline \multirow{2}{*}{$\begin{array}{l}\mathrm{P}-\mathrm{PO}_{4} \\
{[\mathrm{mg} / \mathrm{L}]}\end{array}$} & Inlet & 1.129 & 0.687 & \multirow[t]{2}{*}{$0.20 * / 0.31 * *$} \\
\hline & Outlet & 1.237 & 0.630 & \\
\hline \multirow{2}{*}{$\begin{array}{l}\mathrm{BOD}_{5} \\
{\left[\mathrm{mgO}_{2} / \mathrm{L}\right]}\end{array}$} & Inlet & 5.0 & 7.0 & \multirow[t]{2}{*}{$3.0 * / 6.0 * *$} \\
\hline & Outlet & 6.0 & 6.0 & \\
\hline \multirow{2}{*}{$\begin{array}{l}\mathrm{EC} \\
{[\mathrm{mS} / \mathrm{cm}]}\end{array}$} & Inlet & 0.99 & 0.72 & \multirow[t]{2}{*}{$\leq 1.0^{*} / \leq 1.5^{* *}$} \\
\hline & Outlet & 1.00 & 0.71 & \\
\hline \multirow{2}{*}{$\begin{array}{l}\mathrm{SS} \\
{[\mathrm{mg} / \mathrm{L}]}\end{array}$} & Inlet & 14 & 15 & \multirow[t]{2}{*}{$\leq 25 * / \leq 50 * *$} \\
\hline & Outlet & 19 & 9 & \\
\hline \multirow{2}{*}{$\begin{array}{l}\mathrm{pH} \\
{[-]}\end{array}$} & Inlet & 8.1 & 8.2 & \multirow[t]{2}{*}{$6.0-8.5 * / 6.0-9.0 * *$} \\
\hline & Outlet & 8.2 & 8.1 & \\
\hline
\end{tabular}

${ }^{1}$ Rozporządzenie... (Dz.U. Nr, poz. z 2014)

*very good ecological statue/**good ecological statue

The maximum value was observed at August 2015 and it equaled 100 NTU. We cannot relate this value to any ecological status because turbidity is not a reference indicator in polish low concerning water quality.

Suspended solids refers to small solid particles which remain in suspension in water as a colloid or due to the motion of the water. The maximum value was determinated at inlet of Niewiadoma reservoir at May 2015 (68 mg/L) and its value classifies water as a "below of good ecological status".

The cause of the observed high phosphorus concentration and suspended soils at outlet from pre-reservoir depended on the type of valve used - water outflow takes place through the bottom vent. According to the literature (Pütz and Benndorf 1998) per-reservoir should be equipped with upper, overflow drainage, which is designed to allow water with the lowest concentrations of phosphorus and suspended soils to flow out from the reservoir.

The mean values of electrical conductivity (EC), suspended soils (SS) and $\mathrm{pH}$ at inlets and outlets value of Kupientyn pre-reservoir and Niewiadoma reservoir (table 1) classifies the water to good ecological value. However, the concentrations of $\mathrm{P}_{-} \mathrm{PO}_{4}$ and $\mathrm{BOD}_{5}$ (Table 1) are below of good ecological status (Dz.U. Nr, poz. z 2014). The polish water quality law classifies the ecological status according to rules "one out all out". For this reason, all of examined sampling points are classifies as a below of good ecological status.

\section{CONCLUSIONS}

Based on the studies from October 2013 to September 2015, the Cetynia River water and both reservoirs are highly polluted especially by phosphorous and organic matters $\left(\mathrm{BOD}_{5}\right.$ indicator). However, there is seen the influence of prereservoir on decreasing the $\mathrm{P}-\mathrm{PO}_{4}$ concentration. The inlet $\mathrm{P}-\mathrm{PO}_{4}$ concentration to the main Niewiadoma reservoir is still very high and almost two times higher than the limit value of good ecological statue $(0.31 \mathrm{mg} / \mathrm{L})$. Other examined indicators classifies water to good ecological status.

It is commonly believed that every kind of reservoirs should collect and reduce the nutrient contamination $(\mathrm{N}, \mathrm{P}$, heavy metals). The presented results show that water reservoirs (both pre- and main reservoirs) are a source of water pollution. The reservoirs fed by waters of inadequate or poor quality are an additional source of contamination, which accelerates the process of eutrophication. However, as the literature shows, well-designed pre-reserviors of optimum size 
can remarkably reduce the phosphorus import into reservoirs and help to control eutrophication from non-point sources (Lothar, 2003, Wiatkowski et al. 2006, Lother and Pütz, 2008, Wiatkowski et al. 2010, Wiatkowski et al. 2013).

\section{REFERENCES}

1. Bus, A., Mosiej, J. 2013. Analiza przyczynowo-skutkowa wpływu zbiornika wstępnego Kupientyn na jakość wody w rzece Cetyni. Acta Scientiarum Polonorum. Formatio Circumiectus, No. 12 (2), pp. 13-22. (In Polish)

2. Drizo A. 2012. Innovative phosphorous removal technologies. Clean Technologies and Environmental Policy, 03 http://www.azocleantech.com/article.aspx?ArticleId=226 (accessed on 22/10/2015).

3. Jurik, L., Húska, D., Halászová, K., Bandlerová, A. 2015. Small water reservoirs - sources of water or problems? Journal of Ecological Engineering, Vol. 16, Iss. 4, pp.22-28. http://dx.doi.org/10.12911/22998993/59343

4. Lothar, P., 2003. Nutrient elimination in pre-dams: results of long term studies. Hydrobiol, 504, Iss. 1, pp. 289-295 http://dx.doi.org/10.1023/B:HYDR.0000008528.34920.b2

5. Lother, P., Pütz, K. 2008. Suspended matter elimination in a pre-dam with discharge dependent storage level regulation. Limnologica - Ecology and Management of Inland Waters, 38, Iss. 3-4, pp.3 88-399. http://dx.doi.org/10.1016/j.limno.2008.07.001

6. Mosiej, J., 2011. Rural water management as important factor of sustainable rural development in Poland - some aspects. Rural Development 2011. Fifth International Scientific Conference, Kaunas, Vol. 5, Book 2, pp. 326-331.

7. Mosiej, J. 2014. Sustainable rural development policy in Poland - environmental aspects. Acta Regionalia et Environmentalica , Vol. 2, pp. 65-75.

8. MŚ. 2013. Strategiczny Plan Adaptacji dla sektorów i obszarów wrażliwych na zmiany klimatu do roku 2020 z perspektywą do roku 2030" (SPA 2020). (In Polish)

9. Pütz, K., Benndorf, J. 1998. The importance of pre-reservoirs for the control of eutrophication of reservoirs. Water Science and Technology, Vol. 37, Iss. 2, pp. 317-324. http://dx.doi.org/10.1016/S0273-1223(98)00039-0

10. Wiatkowski M., Czamara W., Kuczewski K., 2006. Wpływ zbiorników wstępnych na zmiany jakości wód retencjonowanych w zbiornikach głównych. IPIŚ PAN, Zabrze. (In Polish)

11. Wiatkowski, M., Czamara, W., Wiatkowska, B. 2010. Wpływ zbiornika Mietków na zmiany jakości wody rzeki Bystrzycy. Woda w badaniach geograficznych, red. T. Ciupa, R. Suligowski, Kielce, ppp. 327-337. (In Polish)

12. Wiatkowski, M., Rosik-Dulewska, Cz., Kuczewski, K., Kasperek, R. 2013. Ocena jakości wody zbiornika Włodzienin w pierwszym roku funkcjonowania (The assessment of water quality in the reservoir Włodzienin in first year of operation). Annual Set The Environment Protection, Vol. 15, pp. 2666-2682. 